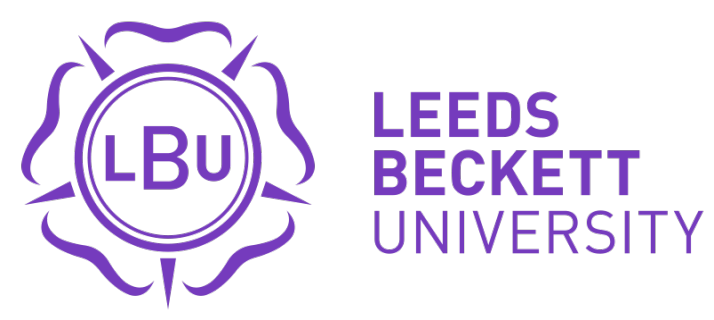

Citation:

Maheshwari, V and Gunesh, P and Lodorfos, G and Konstantopoulou, A (2017) Exploring HR practitioners' perspective on employer branding and its role in organisational attractiveness and talent management. International Journal of Organizational Analysis, 25 (5). pp. 742-761. ISSN 1934-8835 DOI: https://doi.org/10.1108/IJOA-03-2017-1136

Link to Leeds Beckett Repository record:

https://eprints.leedsbeckett.ac.uk/id/eprint/4531/

Document Version:

Article (Accepted Version)

The aim of the Leeds Beckett Repository is to provide open access to our research, as required by funder policies and permitted by publishers and copyright law.

The Leeds Beckett repository holds a wide range of publications, each of which has been checked for copyright and the relevant embargo period has been applied by the Research Services team.

We operate on a standard take-down policy. If you are the author or publisher of an output and you would like it removed from the repository, please contact us and we will investigate on a case-by-case basis.

Each thesis in the repository has been cleared where necessary by the author for third party copyright. If you would like a thesis to be removed from the repository or believe there is an issue with copyright, please contact us on openaccess@leedsbeckett.ac.uk and we will investigate on a case-by-case basis. 


\section{Exploring HR practitioners' perspective on employer branding and its role in organisational attractiveness and talent management}

\begin{tabular}{|r|l|}
\hline Journal: & International Journal of Organizational Analysis \\
\hline Manuscript ID & IJOA-03-2017-1136.R1 \\
\hline Manuscript Type: & Original Article \\
\hline Keywords: & $\begin{array}{l}\text { Employer Branding, Organisational Attractiveness, Human resource } \\
\text { management, Talent management, Banking, Mauritius }\end{array}$ \\
\hline \multicolumn{2}{|l}{} \\
\hline
\end{tabular}

\section{SCHOLARONE ${ }^{\text {tx }}$ \\ Manuscripts}




\section{Exploring HR practitioners' perspective on employer branding and its role in organisational attractiveness and talent management}

\section{Introduction}

The environment is becoming increasingly competitive, and in such a competitive environment, attracting and retaining a talented workforce becomes a key strategic priority for many organisations. Notably, according to Blake (2006), one of the largest costs in different types of organisations is their employee turnover. In addition, Chambers et al. (1998) identified talent scarcity as the second-most-important threat to business success, after competition. Moreover, the global economic recovery following years of depressed growth has accelerated employee turnover, and it has increased employer concerns about talent scarcity and retention (Cascio, 2014). Loss of experienced and skilled employees can lead to a loss of intellectual capital and risk organisations' ability to compete. Therefore, recent studies have emphasized the role of employer branding (EB) in retaining, motivating and engaging employees and attaining increased productivity (Tanwar and Prasad 2016). The concept of employer branding is still evolving, combines the fields of marketing and $\mathrm{HR}$, and has become prominent in recent years for four main reasons: brand power; credibility; employee engagement; and the prevailing labour market conditions (CIPD, 2007). Employer branding has also been presented as a contemporary research field to human resources professionals, the academic community and the corporate world (Backhaus, 2016).

Notably, there seems to be significant growth in employer branding research and practice by organisations worldwide following on from the global financial crisis (GFC), and this form of branding has become of vital concern to senior management. The main objective of such initiatives was to build talent attraction strategies through a financial growth period. Yet, with cutbacks in staffing following the GFC, organisations have shifted focus to the engagement and retention of existing talent pools. Consequently, the economic recession has had a positive influence on the adoption of such strategies, as organisations recognise the real advantages to talent attraction, engagement and retention (Minchington, 2010).

It is well established that building a differentiated and successful service brand requires the commitment of all employees across the service organisation, because these employees embody the service brand in their service interactions (Balmer, 2001; de Chernatony and Cottam, 2009; King and Grace, 2008). Employee commitment has also been found to positively influence acceptance of organisational brand-supporting activities (Shum et al., 2008), internal branding efforts (Punjaisri and Wilson, 2011) and to enhance the adoption of proactive behaviours (Strauss et al. 2009). This was well documented by Wallace's (2013) study that explored the relationship between employee commitment and brand in the banking sector (Wallace et al., 2013).

Research on employer branding has been gaining momentum but has been broad and with limited focus on specific industries and sectors. The banking sector is no different to other sectors in that it requires talent to maintain its core purpose - to design, develop and deliver 
excellent customer service. Yet ineffective talent relationship management has been found to be one of the core issues that led to the 2008 global financial crisis (MacKinnon, 2012). Ganu and Abdulai (2014) capitalised on this gap by reporting a study that examined employer branding and actual employment experience in the banking sector of the African state of Ghana. It also applies to the Mauritian banking sector (MBS) where employer branding is widely viewed with scepticism. With this in mind, this paper examines the perceptions of human resources practitioners in the MBS in relation to employer branding.

The purpose of this study is to identify how EB is perceived for HR practitioners in the MBS as a strategy to "win talent" (Michaels et al., 2001), to identify how well developed EB is as a concept, and finally to identify the extent that HR marketing philosophies underpin EB in MBS.

\section{Theoretical background}

The first steps on the way to the development of the employer brand concept were made in Europe during the early 1990s by two employer branding pioneers, Ambler and Barrow (1996, p.10). Employer branding (EB) emerged from applying marketing principles to the field of personnel recruitment, and has been at the forefront of academic and practitioner research following a growing interest in the areas of talent attraction, management and retention (Cable and Turban 2001; Capowski, 1997; Maurer et al., 1992). More specifically, EB has recently received a lot of attention as a specific form of managing corporate identities by creating, both within and outside the firm, an image of the organisation as a distinct and desirable employer. Lloyd (2002), described EB as the 'sum of a company's efforts to communicate to existing and prospective staff that it is a desirable place to work'. Employer branding has also been discussed using the terminology of 'workplace branding'. However, Love and Singh (2011) argue that the EB concept has received more attention and investigation from the practitioner and consultancy community (such as Towers Watson, Aon Hewiit, Universum Global, Talent solutions and CIPD) than from academics due to the interdisciplinary nature of EB and its significant implications for practice.

EB is concerned with building an image in the minds of the potential labour market, as well as the internal customers, that the company, above all others, is a 'great place to work' (Ewing et al. 2002; Porter, 1985). EB has been defined as "a set of attributes and qualities, often intangible, that makes an organisation distinctive, promises a particular kind of employment experience and appeals to those people who will thrive and perform best in its culture" (CIPD, 2015). Organisations make use of the employer brand to generate a thrilling and exciting impression of them as employers in the minds of current and prospective employees (Oladipo et al., 2013 p. 56). Gaddam (2008) asserts that EB has become prominent in Human Resource Management (HRM), and acts as one of the magic tools of communication for acquiring and retaining talent in this fast-changing technological era. It is further argued that since organisations need to differentiate in order to win the "battle for talent" (Michaels et al., 2001), EB helps them to create a strong and defined identity among employees, and acts as a preferred choice among the future employers for talent recruitment. 
The latest research in the field of EB highlights a mix of marketing principles and recruitment practices, pointing out the similarity between potential customers forming preferences for one brand over another, and potential employees evaluating the attributes of competing jobs and employers (Wallace et al., 2014). Consequently, EB relates to the attraction, engagement, and retention strategy developed by HR to augment an organisation's employment offerings (Minchington, 2015; Ambler and Barrow 1996; Gilly and Wolfinbarger, 1998; Ewing et al. 2002). Moreover, EB has been proposed as a tool to be used by practitioners to connect the HRM strategy to the corporate brand in order to stand out in the talent market (CIPD, 2007). As a result, EB has been commonly portrayed as an assortment of intangible traits and characteristics, presenting a workplace culture as unique, as guaranteeing a specific type of work know-how, and which attracts talent to flourish and achieve optimum performance.

Thus, the notion of the employer brand and subsequent branding process stems from an amalgamation of interdisciplinary research from organisational behaviour, HRM and marketing literature (Drury, 2016; Edwards, 2010), giving rise to a need to investigate the HR marketing philosophy (Schweitzer and Lyons, 2008) as an underpinning philosophy to EB.

\section{Employer branding and HR marketing}

Ganu and Abdulai (2014), in a recent study based in the Ghanaian banking sector, argued that marketing principles should be applied to the field of talent management. In addition, they argued that employer branding uses attraction, engagement and retention schemes, all designed to boost the company brand, in the same way as these schemes would be deployed to sell any product or service (Ganu and Abdulai, 2014). In this context they applied marketing principles to the field of TM. Therefore, some of the challenges that HR practitioners are increasingly facing are related to adding value to the corporate brand (Minchington, 2010).

In particular, in the banking sector, if HR wants to maintain its strategic position, it becomes crucial to break down barriers associated with the understanding of marketing and HR and develop an understanding of how the marketing domains and their relative processes can integrate with HR (McKinsey 2008; Piehler et al., 2015). Furthermore, successful employer branding requires close collaboration between marketing, HR and communications (Minchington, 2015). It should also be aligned to the overall corporate objectives and organisational culture; it should be effectively and transparently communicated; and staff should be given the opportunity to provide feedback on how best to foster talent engagement in line with corporate objectives (CIPD, Mercer, 2010).

Similarly, to regain trust in the banking sector following the aftermath of the GFC, Balan (2013) argues that the application of marketing expertise may augment the worth of EB. As a result, Balan (2013) appeals for the development of an HR marketing philosophy in driving EB strategies. Similarly, in the aftermath of the GFC, the possibility of a proposed 'marriage of convenience' between marketing and HR, in order to solve the traditional problems of talent attraction and retention (Jaros, 1999) could also be considered. This should be based on a marketing orientation focused on talent segments, where employee-value proposition becomes an essential requirement of a strong employer brand. Consequently, e-recruiting has been 
considered as a method whereby the job seeker represents a job consumer, and a target of the organisation's website (Maurer and Liu, 2007). This implies that HR practitioners need to understand key marketing and branding principles, as proposed by Bondarouk et al. (2013), as well as communication and web-based applications that will enable them to benefit from opportunities presented by social media for talent attraction (Bondarouk et al., 2014a). The union of marketing and human resource management theories and the consideration of potential and current talents as customers leads to EB that maintains a customer-oriented rapport, thereby embracing the HR marketing philosophy (Jothi, 2010). Therefore, close collaboration across departments, as well as top management involvement with and support for the employer brand, has become a necessity (Minchington, 2015) for the attraction, engagement and retention of talent (Balan, 2013). In addition, HR practitioners need to develop such key competences as analytical thinking, innovation, and leadership in order to excel at strategic decision-making and obtain support for the employer branding strategy as recommended by Bondarouk et al. (2014b).

Similarly, Wallace et al. (2014 p. 34) argue the need for close coordination between marketing and HR functions. They further emphasise the role of branding and sector image as essential 'magnets' in attracting the talent to support strategic goals and improve the financial performance of the organisation. The adoption of the HR marketing orientation enables organisations to develop a structured template for talent management, to establish priorities and to increase productivity by improving recruitment, retention and commitment of employees. A fragile brand image and employer reputation may result in the attraction of fewer candidates, disengaged and resentful employees, higher turnover, and ultimately in reduced organisational performance (Balan, 2013).

\section{Organisational emphasis in Employer Branding}

Existing literature suggests that organisations have always been concerned about their image as employers in the eyes and minds of their existing and prospective talent pools, which they believe shape the attraction, engagement and retention strategies communicated by the employer brand (Dabirian et al., 2017). As a result, Martin and Cerdin (2014) have made a call for more qualitative research to be conducted based on a novel model of employer branding. This could draw on concepts from signalling theory, reputation management and strategic HRM to support the reputation and talent management challenges increasingly faced by organisations. Likewise, it has been proposed that determinants of workplace attractiveness such as compensation, career opportunities, nature of the job, and corporate culture should be communicated by the employer brand to enable organisations to attract, engage and retain talents and achieve 'employer of choice' status (Chabbra and Sharma, 2014). In this context, certain key dimensions of workplace attractiveness, such as organisation stability, work-life balance, and job security have been recommended as key components of the employer brand, based on employers' and prospective employees' perceptions of workplace attractiveness (Jain and Bhatt, 2015). Therefore, it can be argued that workplace attractiveness depends on a welldesigned employer brand leading to competitive advantage (App et al., 2012). 
Further literature suggests that HR departments have used employer branding to augment the organisation's employment offerings (Barad, 2012; Minchington, 2015). A study conducted by Talent Solutions (2016) surveyed an extensive number of talent acquisition decision makers who work in HR departments. It highlighted that $39 \%$ of participating organisations continue to value quality of hire as the most important metric to monitor performance, and organisations measure this with employee turnover. Therefore, it is no surprise that employee retention is their top priority (32\%), with $59 \%$ of them increasing investment in employer branding compared to last year. In addition, $85 \%$ of respondents consider that the organisation's mission, culture and values need to be communicated as the main elements of the employer brand. $71 \%$ of employers also use employer branding to promote career and development opportunities, while $65 \%$ claimed to specifically dedicate the employer brand for the promoting training and development provisions within organisations. Finally, $76 \%$ of firms considered recruitment advertising and communication materials to be the key resourcing activities determining the employer brand (CIPD, 2007 p. 3).

Another study conducted by the CIPD (2010) revealed that $72 \%$ of HR practitioners utilise their intranet to communicate employer brands. Summarising the CIPD findings, it can be concluded that the HR function is incorporating total reward career development as well as linking it to the overall corporate brand, mission, vision and culture of the organisation - as per the total reward model proposed by Towers Watson (2013). However, research conducted by Balan (2013) reveals that EB strategies are predominantly in the embryonic stage. Perhaps this is because, as Minchington (2015) suggested, corporations view the topic as project-based, or even as an additional administrative burden, instead of a long-term investment for talent relationship management, and have reservations about return on investment (ROI) from such initiatives.

Drawing on previous research conducted by Minchington (2010), Balan (2013) further states that worldwide, less than $20 \%$ of organisations (in the areas surveyed), possessed a welldefined EB strategy:

\section{$\%$ of organisations in given country/region with a well-defined EB strategy}

$\begin{array}{ll}\text { USA and Canada } & 19.7 \% \\ \text { Asia } & 19.4 \% \\ \text { Europe and UK } & 15 \% \\ \text { Australia } & 15 \% \\ \text { Turkey } & 12.3 \% \\ \text { Russia } & 7.6 \%\end{array}$

To date, no findings for Africa have been reported, which again indicates the need for this particular study.

In addition, Minchington (2015) revealed that EB is no more the exclusive sphere of the HR function - previously seen as the conventional guardian. Progressively, HR, marketing and communication professionals are all managing the EB strategy. Nevertheless, in spite of being a top management priority, in this report only $35 \%$ of organisations are reported to have a welldefined EB strategy that needed further developing. The survey findings also reveal that leadership of employer brands is increasingly making its way into other functions. The executive 
team is now up from $2 \%$ in 2009 to $11 \%$, and CEOs from $1 \%$ in 2009 to $10 \%$ - all currently sharing the onus for developing and nurturing EB strategy. A recent study conducted by Universum (2014), categorised employers as "Fatalist" if they are enthusiastically involved in developing employer brands - Fatalist organisations consider talent a valuable, but not indispensable, element of their companies. It is further postulated that HR departments of Fatalist organisations are gradually sharing responsibility for the employer brand with corporate communications and/or marketing functions (Universum, 2014, p.18). In contrast, "Factualist" employers make talent the highest priority, with top management clearly committed to attracting the best and no longer making it the sole responsibility of HR (Universum, 2014), which is worth noting in the context of this study.

It is clear that the image and position of an organisation in the employment market determines workplace attractiveness, which allows potential job applicants to differentiate among competitive employers (Lievens and Slaughter, 2016). As a result, an authentic employer brand enhances workplace attractiveness (Chunyan et al., 2015; Kuron et al., 2015; Wilden et al., 2010), by a means of organisational analysis, thereby attracting high-quality talents who easily integrate and fit with the organisational culture, resulting in improved company financial performance (Lievens and Slaughter, 2016). Employer branding has also been associated with the attraction, engagement and retention of the "right" talents, whose professional values match the organisation's values (Kuron et al., 2015). In relation to this, analysing the roots of EB, the impact of organisational attractiveness on talent attraction and recruitment has been of interest to the research community (Alnaick et al., 2012; Gomes and Neves 2011); however, despite the efforts made by Cable and Turban (2003) to unveil the complex relationship between corporate reputation and talent recruitment there are still research gaps prominent in the field of recruitment branding and its impact on talent attraction (Gomes and Neves ,2011).

Moreover, to be effective and authentic, employer brands should be capable of projecting the personality of the organisation as an attractive employer in order to clearly portray the organisation's ideals, guiding principles and code of conduct for sustainable talent attraction, engagement and retention (Dell and Ainspan, 2010). Edwards (2010) has added that high-level dissemination of the symbolic and instrumental dimensions of workplace attractiveness should also be premeditated as part and parcel of the employer brand to ensure effective publicity. Similarly, Wilden et al. (2010) and Wallace et al. (2014) have highlighted the great importance of employer brand clarity and credibility. In this context, although a study by Alnıaçık et al. (2014) recommends that HR practitioners understand the need to communicate differentiated and customised employee value propositions through respective employer branding strategies, analysing the findings of Minchington (2015) in detail, it can be clearly deduced that the global banking sector - there represented by JP Morgan Chase, Royal Bank of Scotland and Standard Chartered Bank - tends to share responsibility for employer branding among marketing, HR, and communication functions. However, from a wider global perspective, examining the current state of employer branding within organisations still reveals a dearth of research into the African region, especially in the context of the banking sector. Hence, the purpose of this study is to address this gap by considering the views of HR practitioners in the MBS on the use of employer branding for strategic talent relationship management. 


\section{Research context and Methodology}

Research on recruitment and employer branding has typically been situated in Western countries with predominantly individualistic cultures (Van Hoye et al., 2012). The present study investigates EB for service organisations' image and attraction as an employer in a nonWestern culture. The empirical part of this study has been carried out in the Small Island Developing State (SIDS) of Mauritius, which forms part of the region of sub-Saharan Africa. A recent meeting of SIDS representatives in June 2015 came to the conclusion it was going through a period of high cost of living in addition to being adversely affected by an excessive 'brain drain'. However, Mauritius has been able to craft a strong growth-oriented developmental path despite being a small island economy vulnerable to exogenous shocks. Research findings show that the tourism and banking sectors are among the main growth stimulators in Mauritius, and would have been affected by the GFC. As a consequence, irregular stress phases were felt by the financial services sector especially during the periods July 2008-April 2009, and December 2010-January 2013 (Ramlall, 2015). Nevertheless, the 2015 World Bank report conveyed that Mauritius's financial services sector grew by $5.4 \%$ in 2014 . In addition, the report also states that the insurance and financial services sectors contribute $9 \%$ of GDP, and operate with a workforce of over 13,400, representing $2.3 \%$ of the country's total manpower in 2013. Consequently, Mauritius, only a small island state (pop. 1,236,817 at the 2011 census) made judicious use of its human resources to achieve its fundamental development and employment goals and objectives (National Employment Policy for Mauritius, 2014, p.13). Accordingly, an attempt is being made by this study on employer branding and talent management in the MBS to attain this national employment objective.

The MBS comprises 21 banks, of which 7 are local banks, 8 are foreign-owned subsidiaries, 1 is a joint venture, and 4 are branches of foreign banks. All form part of the Mauritius Bankers' Association and are licensed by the Bank of Mauritius to carry out business locally and internationally. Some of the biggest and most reputable international banks are present in Mauritius, and actively carry out international cross-border activities (Mauritius Bankers' Association, 2013). The core values relate to strong ethics, which are the basis of the banking sector and culture. It is acknowledged that teamwork and innovation determine the sector's growth and future. Preserving an ethical workplace through the employment of qualified and dedicated staff is considered critical to the long-term success of the island's banks. In line with honesty and integrity core values, employees are treated with respect and dignity (Mauritius Bankers' Association code of ethics and banking practice 2013, p. 6-7).

In order to gain additional insights and to clarify further the concepts and effects anticipated from the literature, research in the form of semi-structured, in-depth interviews was undertaken. Interviews were conducted based on a theory-derived interview guide in a semi-structured format as recommended by Lee (1999). Semi-structured interviews of open-ended questions, lasting up to 90 minutes, were used to collect data from HR directors, reward managers and talent managers. A participant information sheet and consent form were provided while seeking appointments for interviews. All interviews were recorded and fully transcribed. 
The target population for this qualitative study were HR practitioners from the MBS. HR practitioners have the best knowledge concerning employer branding and talent management, so purposive sampling was employed as suitable for this study (Elo et al., 2014).

Saturation was reached with responses from $27 \mathrm{HR}$ practitioners from 13 banks that agreed to take part in the study (from the total of 21 banks in the MBS). In order to maximise the richness of the insights generated from the interviews, respondents were chosen from a range of banks and profiles (see appendix 1).

\section{Data Analysis}

The interviews were recorded, transcribed, organised and grouped into relevant categories in line with literature. The transcripts were then analysed following typical qualitative procedures (e.g. Glaser \& Strauss, 1967; Strauss \& Corbin, 1998). Thematic analysis was undertaken, as suggested by Braun and Clark (2006), where each of the transcripts was carefully read to understand the motives behind relative responses while referring to the key themes derived from the literature review. Additionally, the Braun and Clark (2013) model of thematic analysis has been employed since it has worked previously with a broad array of research questions surrounding HR practitioners' experiences and insights related to employer branding phenomena in the context of strategic talent relationship management in the MBS. This exercise allowed the development of themes and subthemes for the organisation and presentation of the findings. The researchers also applied the rules of "pattern matching" and comparative methods to draw conclusions (Yin, 1994). To derive further in-depth inferences, the complex relationships among the variables were studied for each bank, using the content analysis and explanation building modes of analysis.

The researchers made use of a deductive approach to coding and analysis, whereby concepts from the literature related to the employer branding domain and functional responsibility for the development of the employer brand were brought to the data for the purpose of coding and data interpretation. The inductive approach was also used to identify emerging codes and themes from the content of the data, which were not present in the literature.

\section{Findings and Discussion}

\section{The state of employer branding in the Mauritian Banking Sector}

Organisations and banks are increasingly competing to attract highly-skilled personnel in various professional areas and therefore those organisations that attract the best talent will have a distinct edge in the marketplace (Harari 1998; Mahroum 2000). Thus, EB becomes too important and too complex to be managed by only one function such as marketing or human resources (Ambler and Barrow 1996; Ritson 2002). Notably, the findings highlighted the need for an integrated cross-functional responsibility, both for developing and managing the employer brand. 
In addition, considering that EB has a direct impact on the corporate reputation and image of a bank, and has close links to corporate branding (Foster et al., 2010), it is imperative that an HR marketing philosophy (Schweitzer et al., 2008) should be in place where each employee is considered as an internal customer and asset (which adds value) from an HR perspective. In relation to this, findings from this study reveal that HR practitioners also seem to be in agreement that there is a strong link between employer branding and strategic talent relationship management through attraction, engagement and retention. Therefore, only when organisations work towards integrating these factors into their employment brand can they hope to successfully compete globally in attracting new employees (Berthon et al. 2005).

Similar understanding of this employer branding concept can be noted in the response from P7, the reward manager of MNE HQ UK A who said:

"I consider employer branding as a modern and innovative philosophy employed for talent management which market leaders are adopting to strengthen their current competitive position in the talent market as well."

This demonstrates that MBS HR practitioners have $b$ the global drivers towards the adoption of EB in organisations, as per the global insights provided by Minchington (2015). HR practitioners of Mauritian banks are fully aware of the current global trend towards the adoption of EB for competitiveness in the talent market. In addition, HR practitioners at a major Mauritian SBUs, even though the acknowledged that they are lagging behind the global trends, for EB development they are unanimously in agreement that EB is the latest strategy which organisations should adopt to gain competitive advantage in the war for talent (Michaels, 2001). It has been additionally emphasised by practitioners that it has become a must for organisations, irrespective of sector, to make a leap towards the adoption of branding for talent attraction, engagement and retention. It is also generally agreed that employer branding has to be unique enough, or at least differentiated from the competitors in order to attract, engage and retain employees.

However, even though most of the participants more fully aware of the role and importance of having a unique $E B$, some of the HR practitioners highlight the need to start by developing a formal structure tailored to the Mauritian talent market and then developing a unique EB. Similarly, there are various and often contradictive perspectives with regards to the role of marketing and/or branding (e.g. Martin and Beaumont, 2003). Despite the concerns and the different perspectives among HR practitioners all the HR respondents employed at SBU banks are confident that all staff will be keen to engage and support the successful design and implementation of an EB strategy. They also pointed out that some of the HR departments have already started thinking and talking about the notion of EB becoming pivotal for achieving the position of employer of choice in competitive talent markets. Thus, for the HR community, EB is now a key strategic tool for building long-term, trust-based relationships with talent.

EB can only be successfully implemented when the members of the HR function are enthusiastic, support the innovation, and voluntarily embrace change. The findings reveal that all of the 13 Mauritian banks that participated in this study are still at the discovery stage of the CIPD 2008 employer brand development and communication four-step process. Nevertheless, 
valuable insights have been gained from the MBS HR professionals to help in gauging the development of employer brand design, which can be extracted from the following statement made by P11, Head of HR and Change MNC HQ MRU (MB 2):

"The values of the bank are integrated without having a formal employer brand. The employer brand has not yet been developed. As HR director I am working on this project and trying to align the employer brand to the formal corporate branding. Actually recruitment is done to be in line and to support the corporate brand and an internal approach to policy is being adopted with a participative management style. As part of external marketing the bank engages in CSR activities to promote the corporate image of the bank."

It is quite clear that there is an understanding of the role and importance of employer branding in MBS; however, it still needs further formalisation and integration with organisational HR practices.

\section{HR professionals' engagement towards the employer branding concept}

The empirical findings suggest that MBS HR practitioners consider the EB concept, similarly to Gaddam (2008), as a modern and innovative philosophy. This philosophy positioned EB as an effective medium to be used by HR practitioners to attract, engage and retain talents in the competitive talent markets. Likewise the views of Michaels et al., (2001) have found empirical support from the statement made by P5 (HR officer MNE HQ South Africa; SBU) who said that indeed:

"EB has a very important role to play in the strategic management of talent since the generation $Y$ talent pool are high technology savvy and very mobile".

In addition, the findings confirm the engagement of MBS HR professionals with EB initiatives, who according to Universum (2014) would be classed as 'fatalist' employers given that they seem to be enthusiastically involved in the design of the EB strategy and they see talent as valuable but not indispensable. Their engagement is broad and at different levels, for instance:

"Talent engagement can be felt by the body language, through facial expressions and the behaviour of the employees". P2, HR manager MNE HQ India (SBU B)

"Engagement is fully present in the HR department which is discerned by the participation in the workshops and activities organized as part of the education and communication activities regarding the branding initiative." P21, Talent management specialist (MB6)

Interestingly, in spite of the engagement claimed by the participants as observed by the researchers, none of the respondents made allusion to the application of branding principles to $\mathrm{HR}$ in their understanding of EB, which supports the findings of a number of previous studies as highlighted in some of earlier key studies (Mosley, 2015; Martin et al., 2009; Edwards, 2010). This shows a lack of in-depth awareness about the concept, which engenders some doubts regarding successful design and implementation of the EB strategy. Nevertheless, overall MBS HR practitioners seem to be very positive with regards to the role and importance of EB as a tool linked to competitive advantage. 


\section{Accountability, responsibility, and ownership of the employer branding strategy}

Davies (2008) argued that certainly there is value in managing the employer brand and a potential danger if no function accepts or is given responsibility for it. However, the findings reveal that HR practitioners employed at MNEs SBUs are adamant that EB strategy will remain dull without collaboration from marketing and corporate communications departments. Additionally, they argue that the support of the finance department is crucial for the implementation of the EB strategy; however, the main responsibility, leadership and guidance should still rest with HR staff, who are considered to be the so-called guardians of talent. As we argued earlier, none of the respondents mentioned marketing principles as an integral part of EB. In addition, the collaboration of communications and event management departments are also sought at MNE HQ UK A, in order to be able to effectively transmit the employer brand message. The collaboration also extends to website design and the use of social media such as Facebook and Linkedln for recruitment and talent segmentation purposes.

Furthermore, it has been stated by the head of HR at a major MNE from South Africa that collaboration with marketing is sought for the design of the employee value proposition (EVP). The centres of excellence in Johannesburg are responsible for the preparation of the generic EB strategy for the whole group, which is then tailored to each country. For Mauritius in particular the focus is on how to develop and retain talent. In contrast, the resourcing and recruitment manager from MNE HQ UK A argues that corporate affairs and marketing are responsible for corporate branding, and they are collaborating for the EB initiatives by focusing on talent attraction, engagement and retention through the application of marketing mapping. Hence, integration with marketing is a routine administrative task for internal recruitment, through Taleo and e-recruitment.

Similarly, the reward manager at the same bank (MNE HQ UK A) strongly believes the EB process should sit within HR. It has also been put forward that the main responsibility for the employer brand should rest with HR, since the management of people is the core responsibility of the HR function. At the bank, the HR department provides content for job advertisements while marketing perform the design, this could be noted from the below extract:

"EB is and should be the total responsibility of the HR department as HR is the driving force for the employer brand", P7 Reward manager MNE HQ UK A.

Similar to the HR practitioners from MNE SBUs, HR practitioners of Mauritian banks perceive the collaboration of the marketing department to be essential, especially for the technical aspects of advertisements and brand philosophy. As argued by the HR officer at one Mauritian bank, the degree of collaboration with marketing depends on the level of support required. When sophisticated or technical marketing-oriented support is required, then help should be sought from the marketing department. Similarly, marketing support is required for educating staff on the EB concept as part of the first-stage preparation for introducing the EB philosophy.

Overall, these findings contribute enormously to the current literature on ownership of the employer brand. Previous studies (apart from Minchington 2015, McKinsey 2008, Vallaster and de Chernatony 2005) have been cautious and hesitant to outline which department should lead 
the branding initiative, even though debates have been undertaken on the necessity for departmental collaboration. HR practitioners from MBS have clearly detailed the areas of collaboration between HR, marketing, communications and events management for the authentic design of an augmented employer brand for sustainable strategic talent retention and management. However, still they hesitate to propose a model where the responsibility and accountability is shared between HR and marketing.

\section{Adoption of the HR marketing philosophy}

MBS HR practitioners strongly recommend the adoption of the HR Marketing philosophy, based on the internal marketing concept (Yu et al., 2014), for the design of the EB strategy, to enable effective strategic talent retention and management (STRM). The practice of HR Marketing in MBS was clearly evidenced in the findings, for example:

"The EVP, the HR Marketing version of the psychological contract is an important aspect of the employer brand. Developing the employer brand requires a marketing orientation and responsibility. Yes, it is important to have the collaboration of the marketing department, as branding has always been the responsibility of marketing. As HR consultant I often seek the help of both internal and external marketing people." P12, HR consultant Indo-Mauritian partnership (MB 3)

However, there is a sense that respondents are not yet ready to go for a fully-integrated HR marketing philosophy to underpin EB, talking more about synergies and collaboration as opposed to co-creation and shared responsibility. On the other hand, findings also revealed concerns around the need to customize marketing principles to people management as advocated by one HR practitioner who expressed great apprehension in one particular way as stating:

"The marketing department wants fast initiatives which are not the same for people management, thus marketing principles cannot be just shifted to the management of people. Rather, key concepts can be customised to the effective management of talent. $E B$ is more profound and should be customised taking into consideration people aspirations and expectations before proposing quick wins. So, HR department has to well plan the EB strategy with collaboration of marketing and communication units. EB is far from being a mere sales promotion exercise". (P27, HR Business Partner MB6)

In above case, the EB was expected to bring outcomes of a sales promotion exercise thus ignoring the voice principle outlined by Martin et al., (2009) which calls for the identification of the authentic voice of different talent groups for effective STRM.

It was evident that HR practitioners of the MBS believe in the use of the HR Marketing framework through the employee value proposition dimensions (Schweitzer and Lyons, 2008) but they are not comfortable with marketing's fast pace of change. There was also a strong emphasis on the effective use of internal marketing to enhance HR Marketing philosophy for their respective organisations. 


\section{Conclusions and Implications}

Although EB is seen as integral part of both HR and marketing strategies, it is a relatively new academic topic. Due to the fact that it is linked to workplace attractiveness, talent management and retention, it has attracted increasing amounts of attention from both marketing and HR academics and practitioners. The findings of our research are relevant to both marketing and $\mathrm{HR}$ managers and academics, as the search for and employment of talented employees requires organisations to invest resources in EB strategies underpinned by a HR marketing philosophy.

Whereas prior academic work is more conceptual and focusing on Western cultures, the current study demonstrates EB's role in strategic relationship management within a contextual and sector-specific setting. It highlights the significance of the concept of $E B$, the complexity of its development within organisations, and its contribution to strategic talent management. It also provides the employers with insights into managing and developing EB by integrating different organisational functions and moving towards a shared responsibility for EB.

Organisations that can attract, retain and develop employees will have a distinct edge in competitive environments and sectors such as MBS. Therefore, employer branding will grow in importance and, we argue, should become a joint responsibility and a common priority for both marketers and HR.

The outcomes of this study call for re-engineering with regards to managerial collaboration in organisations for the successful design and implementation of the EB strategy. In addition, employer branding should be considered as a progressive approach (based on both general branding and HR theories), to make the process of employee attraction, retention and development efficient. In line with the literature (Minchington 2015; Universum 2015), and empirical findings from the MBS, it is clear that the strategic position occupied by the HR function is still at an early stage with regards to the competitiveness of banks as service organisations. This requires the development and maintenance of long-term collaborative and trust-based relationships between the HR and marketing functions. Thus, organisations need to aim to have a strong unity between departmental heads in order to position the organisation as an employer of choice (Guthridge et al., 2008).

In addition, employer branding should become a key part of both HRM and marketing strategies in order to enable a company to attract and engage high-potential employees and to retain talent. Similarly, EB targets should be shared between HR and marketing directors in order for HR marketing philosophies to become part of organisational cultures; but EB is still seen more the responsibility of HR with input from marketing as opposed to a shared responsibility with common targets. However, in order for HR marketing philosophies to become part of organisational cultures, a novel mode of thinking about talent is required across the organisation. The HR function should implement a range of informative internal branding strategies to highlight the organisation's focus on the key areas which contribute to employee retention and employee relations. Similarly, the employer brand itself will have to project the image of an organisation that is caring for its employees, as shown through its career website pages and job advertisements. This dynamic and synergistic relationship between the HR and 
Marketing functions and strategies will also contribute to the enhancement of organisations' corporate image and reputation.

This study has also highlighted the perceptions of HR practitioners on the use of the employer branding strategy for the purposes of strategic talent relationship management in the Mauritian Banking Sector. The findings suggest that EB is considered to be a tool that should reflect the bank's identity, culture, image and reputation, and position the bank as an employer of choice for effective talent attraction, engagement and retention. In addition to the fact that employer branding is still at the embryonic stage, the efforts in Mauritius are concentrated on developing an authentic employer brand strategy for the Mauritian Banking Sector, as a whole.

\section{Future research directions}

Like all academic endeavours, the current study also has certain limitations that constrain the generalisability of the findings and suggest opportunities for further research. Firstly, the study's key respondents were restricted to HR practitioners in the banking sector. Future research could be conducted to get the views of marketing and communications staff on the EB concept, since they have been presented as key contributors to the design and implementation of the EB strategy. Moreover, the study could be extended to other industry sectors, both locally to Mauritius and globally. The views of HR practitioners working at MNE headquarters in Western countries could also be sought, to look for similarities and divergences between their perceptions and those of SBU HR staff located in Mauritius. Likewise, a comparative analysis could be conducted once banks have designed formal employer brands. It would then be possible to compare the views of internal and external talent pools regarding the effectiveness of the brand while focusing on key attraction, engagement and retention drivers. 


\section{References}

Alnıaçık, E., Alnıaçık, U., Erat, S., and Akçin, K. (2014). "Attracting Talented Employees to the Company: Do We Need Different Employer Branding Strategies in Different Cultures?" 10th International Strategic Management Conference Procedia. Social and Behavioral Sciences, 150, pp.336-344.

Ambler, T. and Barrow, S. (1996). 'The employer brand', Journal of Brand Management, 4, pp. 185-206

Hewitt, A., (2015). Aon's Hewitt Model of Employee Engagement, [Online] [available at http://www.aon.com/human-capital-consulting/thought-leadership/talent/aon-hewitt-model-ofemployee-engagement.jsp] accessed on $12^{\text {th }}$ July 2015.

Backhaus, K. (2016) "Employer Branding Revisited" Organization Management Journal, 13, 4, 193-201

Balan, C. (2013). "A marketing perspective of the employer brand in Romania." International conference of the Institute for Business Administration, Bucharest. pp. 41-49.

Balmer, J. M. T. and Greyser, S.A. (2002). 'Managing the multiple identities of the corporation', California Management Review, 44, pp. 72-86.

Berthon, P., Ewing, M. and Lian L. H. (2005) Captivating company: dimensions of attractiveness in employer branding, International Journal of Advertising, 24:2, 151-172.

Blake, R., 2006. Employee retention: What employee turnover really costs your company. July, 24, p.2006.

Bondarouk, T., Ruël, H., Axinia, E., and Arama, R. (2013). What Is the Future of Employer Branding through Social Media? Results of the Delphi Study into the Perceptions of HR Professionals and Academics. Social Media in Human Resources Management Advanced Series in Management, pp. 23-57.

Bondarouk,T., Ruël,H., Axinia,E., Arama, R, (2014) "What Is the Future of Employer Branding Through Social Media? Results of the Delphi Study into the Perceptions of HR Professionals and Academics" Social Media in Human Resources Management.pp 23-57.

Bondarouk, T., Marsman, E., and Rekers, M. (2014b). HRM, Technology and Innovation: New HRM Competences for Old Business Challenges? Human Resource Management, Social Innovation and Technology Advanced Series in Management, Vol.14, pp.179-215.

Bouton, K (2015) "Recruiting for Cultural Fit" Harvard Business Reviewhttps://hbr.org/2015/07/recruiting-for-cultural-fit 
Braun, V., and Clarke, V. (2013). Teaching thematic analysis: Overcoming challenges and developing strategies for effective learning. The Psychologist, 26 (2), pp. 120-123. ISSN 09528229.

Braun, V., and Clarke, V. (2006). Using thematic analysis in psychology. Qualitative Research in Psychology, 3(2), pp. 77-101. ISSN 1478-0887

Burke, R.J., Martin, G. and Cooper, C.L., (2011) Corporate reputation: Managing opportunities and threats. Gower Publishing, Ltd.

Cable, D. M., and Turban, D. B. (2001). 'Establishing the dimensions, sources and value of job seekers' employer knowledge during recruitment'. In G. R.Ferris (ed.), Research in Personnel and Human Resources Management, pp. 115-163. New York: Elsevier Science.

Cable, D. M., and Turban, D. B. (2003). "The value of organizational reputation in the recruitment context: A Brand-Equity perspective", Journal of Applied social psychology, 33, 11 pp 2244-2266

Cascio, W. F. (2014). Leveraging employer branding, performance management and human resource development to enhance employee retention. Human Resource Development International, 17, 121-128.

Capowski, G. (1997). 'Dealing with the labor shortage from the inside out', HR Focus, 74, p. 2.

Chabra, N.L., and Sharma, S. (2014), "Employer branding: strategy for improving workplace attractiveness", International journal of Organizational analysis, vo. 22 Iss 1 pp.48-60

Chambers, E. G., Foulon, M., Handfield-Jones, H., Hankin, S. M., and Michaels, E. G. (1998). The war for talent. The McKinsey Quarterly, 3, 44-57.

Chunyan X., Bagozzi, R. P., and Meland, K.V., (2015),"The impact of reputation and identity congruence on employer brand attractiveness", Marketing Intelligence and Planning, Vol. 33 Iss 2 pp. $1-35$

CIPD (2007). Employer branding: the latest fad or future of HR? London. Chartered Institute of Personnel and Development.

CIPD (2008), "Employer branding: a no-nonsense approach"

CIPD (2010), "Employer branding and total rewards research report."

CIPD and Mercer (2010), "Understanding the links between employer branding and total reward: An overview of our research findings and the implications for reward" [Online] [Available at https://www.londoncouncils.gov.uk/download/file/fid/4475, accessed on $20^{\text {th }}$ February 2016] 
CIPD (2015). Employer branding: a no-nonsense approach. London. Chartered Institute of Personnel and Development.

Dabirian, A., Kietzmann,J., Diba H., (2017) "A great place to work!? Understanding crowdsourced employer branding", Business Horizons.

Davies, G., (2008),"Employer branding and its influence on managers", European Journal of Marketing, Vol. 42 Iss 5/6 pp. 667 - 681 .

De Chernatony, L., and Cottam, S. (2009). Interacting contributions of different departments to brand success. Journal of Business Research, 62(3), 297-304.

Dell, D., Ainspan, N., Bodernberg, T., Troy, K., and Hickey, J. (2001),"Engaging employees through your brand (research report 1288-01-RR). New York: the Conference Board.

Drury, P. ( 2016). "Employer branding: Your not-so-secret weapon in the competition for young workers", Human Resource Management international Digest, 24(3), pp.29-31

Edwards, M. R. (2010). An integrative review of employer branding and OB theory. Personnel Review, Vol.39, No.1, pp. 5-23.

Ewing, M. T. and Caruana, A. (1999) An internal marketing approach to public sector management: the marketing and human resources interface. International Journal of Public Sector Management, 12(1), pp. 17-26.

Ewing, M. T., Pitt, L. F., de Bussy, N. M. and Berthon, P. (2002) Employment branding in the knowledge economy. International Journal of Advertising, 21(1), pp. 3-22.

Flick, U. (2011). An introduction to qualitative research. 4th edition, Sage Publications.

Foster, C., Punjaisri, K., and Cheng, R. (2010). Exploring the relationship between corporate, internal and employer branding. Journal of Product and Brand Management pp. 401-409.

Gaddam, S. (2008). Modeling Employer Branding Communication: The Softer Aspect of HR Marketing Management. Hyderabad. ICFAI University Press.

Ganu, J., and Abdulai, I. (2014). "Linking Employees' Employment Experience and Employer Brand Offer: An Assessment of the Banking Sector in Ghana." International Conference on Arts, Economics and Management (ICAEM '14) March 22-23, 2014 Dubai (UAE).

Gardner, W. L, Reithel, B. J, Cogliser, C. C, Walumbwa, F. O. and Foley, R. T. (2012). "Matching personality and organizational culture: Effects of recruitment strategy and the fivefactor model on subjective person-organisation fit", Management Communication Quarterly, issue 26(4), pp585-622. 
Gilly, M. C., and Wolfinbarger, M. (1998). "Advertising's internal audience." Journal of Marketing, 62(1), pp. 69-88.

Glaser, B., \& Strauss, A. (1967). The discovery of grounded theory. Chicago: Aldine.

Gomes, D., and Neves, J. (2011). “Organisational attractiveness and prospective applicants' intention to apply", Personnel Review, Vol.40 No.6 pp 684-699

Guthridge, M., Komm, A. B., and Lawson, E. (2008). "Making talent a strategic priority." McKinsey Quarterly, 1, 48.

Harari, O. (1998) "Attracting the best minds." Management Review, 87(4), pp. 23-26.

Hurrell, S.A., and Scholarios, D. (2013). "The people make the brand: Reducing social skills gaps through person-brand fit and human resource management practices." Journal of Service Research pp. 1-14.

Jain, N., Bhatt, P. (2015). "Employment preferences of job applicants: unfolding employer branding determinants", Journal of Management Development, 34(6), pp. 634-652

Jaros, J. (1999). HR and Marketing: a marriage of convenience. Flex Execs Management Solutions.

Jones, B., Temperley, J., Lima, A. (2009). "Corporate reputation in the era of web 2.0: the case of Primark” Journal of Marketing Management, vol 25, No 9-10, pp 927-939

Jothi, V. (2010), HR Marketing [Online] [Available at: www.recruitingblogs.com/profiles/blogs/hrmarketing, accessed on 10 January 2015]

King, C. and Grace, D. (2008). "Internal branding: exploring the employees' perspective." Brand Management, 15(5), 358-372.

Kristof-Brown, A.L. (2000). "Perceived applicant fit: distinguishing between recruiters' perceptions of person-job and person-organisation fit." Personnel Psychology Vol.53, pp. 643671.

Kuron L. K. J., Lyons S. T., Schweitzer L. S.W., Ng E. (2015). "Millennials' work values: differences across the school to work transition" Personnel Review Vol. 44 No. 6, 2015 pp. 991 1009

Lievens, F., Slaughter, J. E. (2016). "Employer Image and Employer Branding: What We Know and What We Need to Know" Annual Review of Organizational Psychology and Organizational Behavior Contents Volume 3 
Linkedln Talent Solutions (2016). "Global Recruiting Trends 2016". [Online] [Available at: https://business.linkedin.com/talent-solutions/recruiting-resources-tips, accessed $17^{\text {th }}$ May 2016].

Lee, T. (1999). Using qualitative methods in organizational research. Thousand Oaks, CA: Sage.

Lloyd, S. (2002). "Branding from the inside out." Branding Review Weekly, 24(10), pp. 64-66.

Love L. F., Singh, P. (2011). "Workplace Branding: Leveraging Human Resources Management Practices for Competitive Advantage Through "Best Employer" Surveys Journal of Business Psychology, 26, pp.175-181.

MacKinnon R (2012). "Banking on talent: The context for development in financial services" whitepaper, Talent Q Ltd.

Mahroum, S. (2000). "Highly skilled globetrotters: mapping the international migration of human capital." RandD Management, 30(1), pp. 23-31.

Martin, G. and Beaumont, P.B. (2003). "Branding and People Management: What's in a Name?", CIPD, London.

Martin, G., and Groen-in-'t-Woud, S. (2011). "Employer branding and corporate reputation management in global companies: a signalling model and case illustration." In: Scullion, H., and Collings, D. (eds.) Global Talent Management. Routledge, London, pp. 87-110. ISBN 9780415871709.

Martin, G., Cerdin, J. (2014). "Employer Branding and Career Theory: New Directions for Research", in Sparrow et al. (eds.) Strategic Talent Management: Contemporary Issues in International Context, Cambridge: CUP.

Maurer, S. D., Howe, V. and Lee, T. W. (1992). 'Organisational recruiting as marketing management: an interdisciplinary study of engineering graduates', Personnel Psychology, 45, pp. 807-833.

Maurer, S.D., and Liu, Y. (2007). "Developing effective recruitment websites: Insights for managers from marketers." Business Horizons, Issue 50, pp. 305-314.

Mauritius Bankers Association. (2014) Profile of Banks.

Michaels, E., Handfield-Jones, H., Axelrod, B. (2001). The War for Talent. Boston: Harvard Business School Press.

Minchington, B. (2010). Employer brand leadership: A global perspective. Collective Learning Australia.

Minchington, B., 2015. Who must lead employer branding?: international waters-employer branding. HR Future, 9(Sep 2015), pp.14-17. 
Mosley, R. (2015). CEOs need to pay attention to employer branding. Harvard Business Review.

Oladipo, T., Iyamabo, J., and Otubanjo, O. (2013). "Employer Branding: moulding desired perceptions in current and potential employees." Journal of Management and Sustainability, 3(3), pp. 55-65.

Pla, R. L. (2007). “Employment Branding: Who's Responsible?” NZ Marketing Magazine, 26(11).

Piehler, R., Hanisch, S., and Burmann, C. (2015). "Internal Branding - Relevance, Management and Challenges." Marketing Review St. Gallen pp. 52-60.

Porter, M. E., and Gartner, W. B. (1985). "Competitive Strategy, Competitive Advantage" Academy of Management Review, Vol. 10, No. pp. 873-875

Punjaisri, K. and Wilson, A. (2011). "Internal Branding process: Key mechanisms, outcomes and moderation factors." European Journal of Marketing, 45(9/10), 1521-1537.

Ritson, M. (2002) "Marketing and HE collaborate to harness employer brand power." Marketing, 24 October, p. 24.

Ramlall, I. (2015). "Mauritius Financial System Stress Index: Estimating the Costs of the Subprime Crisis." Journal of African Business, 1-31

Ryan, A.M., Sacco, J.M., McFarland, L.A. and Kriska, S.D. (2000). Applicant self-selection: Correlates of withdrawal from a multiple hurdle process. Journal of applied psychology, 85 (2), 163.

Schweitzer, L., and Lyons, S. (2008). "The market within: A marketing approach to creating and developing high-value employment relationships." Business Horizons, Elsevier Science Inc.

Shum, P., Bove, L., Auh, S., (2008). "Employees' affective commitment to change: The key to successful CRM implementation.” European Journal of Marketing, 42(11/12), 1346-1371.

Strauss, K., Griffin, M. A., and Rafferty, A. (2009). "Proactivity directed toward the team and organisation: the role of leadership, commitment and role-breadth self-efficacy." British journal of Management, 20, 279-291.

Strauss, A., \& Corbin, J. (1998). Basics of qualitative research. Thousand Oaks, CA: Sage.

Tanwar, K., Prasad, A. (2016). "Exploring the Relationship between Employer Branding and Employee Retention." Global Business Review, 17(3S) 
Tanwar, K., Prasad, A. (2017). "Employer brand scale development and validation: a second order factor approach ", Personnel Review, 46(2), pp. 389-409

Towers Watson (2013). Creating a Sustainable Employment Deal: Getting EVP and Total Rewards Right. Global Talent Management and Rewards Study 2012 - 2013.

Universum Global. (2014). Talent can now choose their employers. Did they choose you as World's Most Attractive?

Vallaster, C., and de Chernatony, L. (2005). "Internationalisation of services brands: The role of leadership during the internal brand building process." Journal of Marketing Management, 21(1), 181-203.

Van Hoye, G., Bas, T., Cromheecke, S., and Lievens, F., (2012) "The Instrumental and Symbolic Dimensions of Organisations' Image as an Employer: A Large-Scale Field Study on Employer Branding in Turkey" APPLIED PSYCHOLOGY: AN INTERNATIONAL REVIEW, 2013, 62(4), 543-557.

Wallace, E., de Chernatony, L., and Buil, I., (2013). "Building bank brands: how leadership behaviour influences employee commitment.” Journal of Business Research 66, 165-171.

Wallace, M., Lings, I., Cameron, R., and Neroli, S. (2014). A"ttracting and Retaining Staff: The Role of Branding and Industry Image". R. Harris, and T. Short (eds.). Workforce Development, DOI 10.1007/978-981-4560-58-0_2, 19 @ Springer Science + Business Media Singapore.

Williamson I.O., King J.E., Lepak D., Sharma A (2010), "Firm reputation, recruitment websites and attracting applicants" Human resource management, Vol.49 No.4 pp 669-687.

Wilden, R., Guderagn, S., and Lings, I. (2010), "Employer branding: strategic implications for staff recruitment." Journal of Marketing Management, Vol.26 No.1-2, pp 56-73.

Yin, R. K. (1994). Case Study Research Design and Methods. Newbury Park, CA: Sage.

Yu, T, Huang, S. Rundle-Thiele (2014), "The moderating effect of cultural congruence on the internal marketing practice and employee satisfaction relationship: An empirical examination of Australian and Taiwanese born tourism employees". Tourism Management 42, pp.196-206.

\section{Reports}

Background Document - SIDS meeting - Mauritius 24-26 June 2015.

Bank of Mauritius financial stability report February 2015. 
WORLD BANK 2015 Mauritius Jun 23, 2015 World Bank. 2015. Mauritius - Systematic Country Diagnostic. Washington, D.C. World Bank Group.

National employment policy for Mauritius (fourth draft) ministry of Labour, industrial relations and employment republic of Mauritius September 2014. 


\section{Appendix 1}

\begin{tabular}{|c|c|c|}
\hline $\begin{array}{c}\text { Participant } \\
\text { No./bank status }\end{array}$ & Job title & Years of experience \\
\hline \multicolumn{3}{|c|}{ MNE SBUs } \\
\hline $\begin{array}{l}\text { P1 } \\
\text { MNE SBU } \\
\text { India }\end{array}$ & Manager HR/Administration & $\begin{array}{l}26 \text { years of experience as branch } \\
\text { manager } \\
\text { HR manager since October } 2013 \text { he } \\
\text { was called upon to take the } \\
\text { responsibility, as a promotion }\end{array}$ \\
\hline $\begin{array}{l}\text { P2 } \\
\text { MNE SBU } \\
\text { India }\end{array}$ & HR manager & 14 years in the HR profession \\
\hline $\begin{array}{l}\text { P3 } \\
\text { MNE SBU } \\
\text { France }\end{array}$ & HR manager & $\begin{array}{l}10 \text { years at the bank, } 3 \text { years as } \mathrm{HR} \\
\text { manager }\end{array}$ \\
\hline $\begin{array}{l}\text { P4 } \\
\text { MNE SBU } \\
\text { South Africa }\end{array}$ & Head of HR & 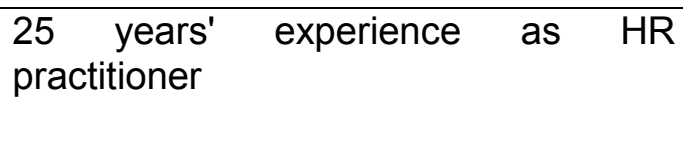 \\
\hline $\begin{array}{l}\text { P5 } \\
\text { MNE SBU } \\
\text { South Africa }\end{array}$ & HR officer & $\begin{array}{l}6 \text { months as HR officer AT BANK } \\
2.5 \text { years as HR officer at Nestle }\end{array}$ \\
\hline $\begin{array}{l}\text { P6 } \\
\text { MNE } \\
\text { HQ UK A }\end{array}$ & Resourcing manager & 14 years in HR profession \\
\hline $\begin{array}{l}\text { P7 } \\
\text { MNE HQ UK A }\end{array}$ & Reward Manager & 3.5 years \\
\hline $\begin{array}{l}\text { P8 MNE } \\
\text { HQ UK A }\end{array}$ & Head of HR & 16 years \\
\hline $\begin{array}{l}\text { P9 } \\
\text { MNE HQ UK B }\end{array}$ & HR manager & $\begin{array}{l}2 \text { years in current position before } 6 \\
\text { years at MNE HQ South Africa plus } 8 \\
\text { years' experience in HR }\end{array}$ \\
\hline \multicolumn{3}{|c|}{ MAURITIAN BANKS (MB) } \\
\hline $\begin{array}{l}\text { P10 } \\
\text { MB } 1\end{array}$ & $\begin{array}{l}\text { HR position: customer service } \\
\text { representative }\end{array}$ & 4 years \\
\hline $\begin{array}{l}\text { P11 } \\
\text { MB } 2\end{array}$ & Head of HR and Change & 4 years \\
\hline $\begin{array}{l}\mathrm{P} 12 \\
\text { MB } 3\end{array}$ & HR Consultant & $\begin{array}{l}15 \text { years at Mauritius Union and } \\
\text { Standard Bank }\end{array}$ \\
\hline $\begin{array}{l}\text { P13 } \\
\text { MB } 4\end{array}$ & HR Head & 3 years \\
\hline $\begin{array}{l}\text { P14 } \\
\text { MB } 5\end{array}$ & Vice President of Finance & $\begin{array}{l}2 \text { years in HR } \\
14 \text { years in Financial }\end{array}$ \\
\hline $\begin{array}{l}\mathrm{P} 15 \\
\text { MB } 6\end{array}$ & \begin{tabular}{|l|l|} 
Group Head of Human \\
Resources
\end{tabular} & over 25 years \\
\hline $\begin{array}{l}\text { P16 } \\
\text { MB } 6\end{array}$ & Learning and Talent Manager & 8 years \\
\hline
\end{tabular}




\begin{tabular}{|l|l|l|}
\hline $\begin{array}{l}\text { P17 } \\
\text { MB 6 }\end{array}$ & HR operations Manager & years \\
\hline $\begin{array}{l}\text { P18 } \\
\text { MB 6 }\end{array}$ & $\begin{array}{l}\text { Rewards and benefits } \\
\text { Manager }\end{array}$ & 21 years \\
\hline MB 6 & HR services Manager & 14 years \\
\hline $\begin{array}{l}\text { P20 } \\
\text { MB 6 }\end{array}$ & Talent Management Specialist & 12 years \\
\hline $\begin{array}{l}\text { P21 } \\
\text { MB 6 }\end{array}$ & Talent Management Specialist & 12 years \\
\hline $\begin{array}{l}\text { P22 } \\
\text { MB 6 }\end{array}$ & Talent Management Specialist & 3.5 years \\
\hline P23 & Talent & \\
MB 6 & Coordinators & 17 years \\
\hline P24 & Talent Management & 14 years \\
MB 6 & Coordinator & 6 years \\
\hline P25 & HR Business Partner & 7 years \\
MB 6 & HR Business Partner & 10 years \\
\hline P26 & & \\
MB 6 & HR Business Partner & \\
\hline P27 & & \\
MB 6 &
\end{tabular}

